ISSN 0258-7122

Bangladesh J. Agril. Res. 37(1): 27-37, March 2012

\title{
OPTIMUM WATER USE IN CONSERVATION TILLAGE FOR WHEAT CULTIVATION
}

\author{
K. K. SARKER ${ }^{1}$, P. K. SARKAR ${ }^{2}$, A. Z. SARKER ${ }^{2}$ \\ A. M. F. T. ISLAM ${ }^{2}$ AND WANG XIAOYAN ${ }^{1}$
}

\begin{abstract}
Conservation tillage system offers numerous benefits over intensive tillage system. This experiment was conducted on conservation tillage using zero tilldrill, power tiller operated seeder (PTOS) and bed planter along with farmer's practice of tillage by rotary tiller under different irrigation levels at Wheat Research Centre (WRC), Nashipur, Dinajpur. Irrigation water was applied by 5 irrigation levels at different growth stages of the crop. The irrigation levels were $\mathrm{I}_{0}$ (No irrigation), $\mathrm{I}_{1}$ (17-21 DAS), $\mathrm{I}_{2}$ (17-21 DAS + 50-55 DAS), $\mathrm{I}_{3}$ (17-21 DAS + 50-55 DAS + 75-80 DAS), and $\mathrm{I}_{4}$ (17-21 DAS + 35-40 DAS + 50-55 DAS + $75-80$ DAS). It was observed that the sowing cost was reasonably reduced than that of the farmer's practice. Seasonal water use was less in PTOS than other tillage methods. Grain yield was significantly affected by tillage methods. The higher grain yield was found from PTOS, bed planting, and zero tillage than that of farmer's practice. There was no significant difference within the interaction effect of tillage methods and irrigations. The effect of irrigation level was found highly significant on grain yield. Water use efficiency increased with decrease of irrigation water use and decreased with increase of irrigation. Average yields in all tillage methods under $\mathrm{I}_{1}, \mathrm{I}_{2}, \mathrm{I}_{3}$, and $\mathrm{I}_{4}$ irrigation levels were found to increase by $33,43,52$, and 51 percent, respectively, compared to that of $\mathrm{I}_{0}$.
\end{abstract}

Keywords: Conservation tillage, zero till-drill, PTOS, bed planting, and irrigation water.

\section{Introduction}

Cultivation and tillage play an important role in agriculture. Traditional soil cultivation system in the tropics and subtropics, with intensive soil tillage, will end in soil degradation and loss of crop productivity. This will result in poverty, exodus of farmers from rural areas, resulting in an increase of city slums and marginal population, and finally in social conflicts (http://www.Soils.wisc.edu/ stro). Conservation tillage is a set of practices that leave crop residues on the surface to increase water infiltration and reduce erosion. These practices are used in conventional agriculture to reduce the effects of tillage on soil erosion. It uses some of the principles of conservation agriculture (CA) but has more soil disturbance (http://www.fao.org/ag/ca/1a-html). Conservation agriculture aims to achieve sustainable and profitable agriculture and subsequently aims at

${ }^{1}$ Department of Agricultural Engineering, China Agricultural University, P. O. Box No. 46, Beijing 100083, P. R. China, ${ }^{2}$ Bangladesh Agricultural Research Institute (BARI), Joydebpur, Gazipur-1701, Bangladesh. 
improving livelihoods of farmers. Conservation agriculture manipulates the soil to obtain optimum growth conditions for a crop under increased soil fertility from soil and water conservation. Conservation tillage with management strategies and proper selection can protect the water movement. Tillage of the field before sowing increase initial stands and their survival. Excessive tillage results in late planting and reduces yields of wheat. Tillage operations vary according to water availability, soil texture, topography and farmer's preference for a particular type of culture (De Datta, 1981). Tillage practices that provide conditions for rapid water intake and for temporary storage of water on the soil surface or in the tilled layer help prevent water run-off (Sarker, 1987). Farmers are adopting the new resource conservation technologies (RCTs). At present, it is very important due to shortage of labours and has to be proven in agroecological zone of Bangladesh for profitable agricultural production with environmental concerns and sustainability. Justice et al. (2004) reported that Chinese Power Tiller Operated Seeder (PTOS) was modified for strip tillage. This was also used to plant rabi crops into aman rice residue during October/November. One pass tillage (full tillage) was compared to strip tillage. In the strip tillage treatment, half of the tiller blades were removed and the seeds were placed into the tilled strips. Field capacity of the seed drill increased by 25 percent, fuel consumption was reduced by 20 percent and planting cost was reduced by 8 percent compared to those of full tillage treatment. Zero tillage is possible just after rice harvest and present of residual available soil moisture whereas wheat planting is delayed after rice harvest in case of farmers have to pre-irrigate their fields before planting. Zero tillage save this irrigation. Saving in water also comes from the fact that irrigation water advances quicker in untilled soil compared to tilled soil. Aslam et al. (1993) showed that zero tillage establishment of wheat after rice gave yields that were equal or even better than that when planted after normal tillage. It was mainly explained by timely planting in the zero-till plots. Bed planting practice is grown in many parts of the world to reduce the cost of production and irrigation water (Abdelhadi et al., 2006). Wheat is a strategic crop and is produced exclusively under irrigation during the short winter season between November and March. Wheat is the second most important staple food in Bangladesh after rice and its production per unit area has increased from 1.95 to $2.13 \mathrm{t} / \mathrm{ha}$ in 2008 (WRC, 2008). Productivity per unit area has to be improved due to increasing population growth under limited cultivated land. The optimum use of irrigation water should be an important strategy for increasing agricultural production in Bangladesh. Generally, wheat is sown in November and harvested in March (90 - 115 Days). Loam soils are preferable for good yield of wheat. Seasonally about $250-350 \mathrm{~mm}$ water is required for wheat production with $1.5-4.0 \mathrm{~mm}$ as daily evapo-transpiration (Sattar, 2004). Water is the most important factor and critical input for successful crop production. Water should be utilized for optimum and economic yield. Modern high yielding 
crop practice methods can be sustained only with good water control and management at the farm level. Water is also the limiting factor for increased food and fiber production to meet the demand of an ever growing population under increasing competition with other uses of water (Municipal, industrial, environmental, etc.). The optimum population of the planet earth depends to a large extent on the availability of water for both raised and irrigated agriculture to grow crops and produce food in the most efficient way (Ali, 2009). Therefore, this research has been undertaken the emphasis on soil conservation and water requirement, improving water use efficiency and relative profitability of conservation agriculture through appropriate crop, fertilizer use and efficient utilization of water and other inputs for wheat cultivation.

The specific objectives were to:

(i) compare the sowing cost for different tillage methods;

(ii) determine the seasonal water use in different tillage;

(iii) determine the effects of tillage and irrigation water on crop yield.

\section{Materials and Method}

\section{Physical environment of the study area}

The study was conducted during the rabi season of 2008-09 at the Wheat Research Centre (WRC), Nashipur, Dinajpur. The site was situated at $25^{0} 45^{\prime} \mathrm{N}$ latitude and $88^{\circ} 40^{\prime} \mathrm{E}$ longitude. The topography of the study area was mainly medium high land and moderately well drained and falls under the old Himalayan Piedmont Plain. The topsoil was non-calcareous brown flood plain (BBS, 2004). The weather of the study area is sub-tropical. During the growing season of wheat, the mean 15 days average weather data were collected from the WRC weather station. Soil samples were collected from $0-15,15-30$, and $30-$ $45 \mathrm{~cm}$ depth of the experimental plots randomly to determine soil moisture, bulk density and field capacity by oven dry method. The data on the other major property of soil, such as soil type was collected from the research report of Bodruzzaman and others (2003).

\section{Management of water regimes}

The field experiment was laid out in two factors Randomized Complete Block Design (RCBD) using strip plots arrangement and replicated thrice. The unit plot size was $25 \mathrm{~m}^{2}$. The research was conducted in zero tillage (ZT), bed planting (BP), power tiller operated seeder (PTOS), and farmer's practice (FP) under different irrigation levels. Irrigation schedule was done in conformation with recommended irrigation practices in the experimental plots (Khair, 1995). Treatment combination comprised 5 levels of irrigation during wheat growth 
stages at $\mathrm{I}_{0}$ (Irrigation no.), $\mathrm{I}_{1}$ (17-21 DAS), $\mathrm{I}_{2}\left(17-21 \mathrm{DAS}+50-55\right.$ DAS), $\mathrm{I}_{3}$ (17$21 \mathrm{DAS}+50-55 \mathrm{DAS}+75-80 \mathrm{DAS})$, and $\mathrm{I}_{4}(17-21 \mathrm{DAS}+35-40 \mathrm{DAS}+50-55$ DAS $+75-80$ DAS). Irrigation scheduling and application rate of each irrigation water for wheat was based on field capacity. Each levee of the plots was compacted manually and used plastic sheet to prevent the seepage and lateral movement. The rainfall (Rf) data was measured using rain gauge. The actual requirement was the depth of water needed to bring the crop rooting zone to field capacity uniformly throughout the field. The net irrigation depth was calculated from the following formula:

$\mathrm{d}=\frac{\mathrm{P}_{\mathrm{W}} \mathrm{A}_{\mathrm{S}} \mathrm{D}}{100}$

Where, $d=$ Net depth of irrigation water to be applied during irrigation, $\mathrm{cm}$

$$
\begin{aligned}
A_{s} & =\text { Apparent specific gravity } \\
D & =\text { Rooting depth to be irrigated, } c m \\
P_{w} & =(F C-R L)
\end{aligned}
$$

Here,

$$
\begin{aligned}
& \mathrm{FC}=\text { Field capacity, } \% \\
& \mathrm{RL}=\text { Residual soil moisture level before irrigation, \% }
\end{aligned}
$$

The Depth of rooting was considered $45 \mathrm{~cm}$. It is reported that $70 \%$ of total moisture is extracted from the $50 \%$ effective root zone depth (Michael, 1996)

The seasonal crop water use was calculated by the following relationship:

$$
\mathrm{SWU}=\mathrm{NIR}+\mathrm{Rf}+\sum \frac{\mathrm{n}\left(\mathrm{M}_{\mathrm{bi}}-\mathrm{M}_{\mathrm{ei}}\right)}{\mathrm{i}=1 \quad 100} \times \mathrm{A}_{\mathrm{Si}} X_{D_{\mathrm{i}}}
$$

Where, $\mathrm{SWU}=$ Seasonal water use, $\mathrm{mm}$

$$
\begin{aligned}
\mathrm{NIR} & =\text { Total irrigation water depth, } \mathrm{mm} \\
\mathrm{Rf} & =\text { Seasonal rainfall, } \mathrm{mm}
\end{aligned}
$$

$\mathrm{M}_{\mathrm{bi}}=$ Moisture percentage at the beginning of the season in the $i^{\text {th }}$ layer of the soil

$\mathrm{M}_{\mathrm{ei}}=$ Moisture percentage at the end of the season in the $\mathrm{i}^{\text {th }}$ layer of the soil

$\mathrm{n}=$ No. of soil layers in the root zone, D, which was considered of three of layers,

$0-15,15-30$, and $30-45 \mathrm{~cm}$. 
$\mathrm{Di}=$ Depth of the $\mathrm{i}^{\text {th }}$ layer of soil within the root zone, $\mathrm{mm}$

$\mathrm{A}_{\mathrm{si}}=$ Apparent specific gravity of $\mathrm{i}^{\text {th }}$ layer of soil

Water use efficiency was used in evaluating the yield performance and water management practices. The water utilized by the crop was calculated by the following relationship:

Water use efficiency $($ WUE $)=\frac{\text { Crop yield }\left(\mathrm{kg} / \mathrm{m}^{2}\right)}{\text { Seasonal crop water use }(\mathrm{m})}, \mathrm{kg} \mathrm{m}^{-3}$

\section{Cultural practices}

A pre-sowing irrigation was applied for proper seed germination. A high yielding variety BARI Gom-23 (Bijoy) was sown in the experimental plots on 28 November 2008 with the help of zero till- drill (Fig. 1), Bed former (Fig. 2), PTOS (Fig. 3), and farmer's practice (Fig. 4) at the rate of $120 \mathrm{~kg} / \mathrm{ha}$. Seeding was done without land preparation by zero till-drill. Bed was formed and seeding was done without prior land preparation. Bed was formed two rows accommodating wheat. Furrow to furrow was $55-56 \mathrm{~cm}$. Bed height was $12-13$ $\mathrm{cm}$. Irrigation water was applied to the furrows between beds. Ploughing, seeding, and leveling were done through one pass full tillage by PTOS. Tractor operated rotavator was used in farmer's practice for broadcast sowing. Data on sowing cost by tractor operated rotavator were collected from different locations of Dinajpur region. Seeds were treated with Provax-200@3 g/ kg of seed. Fertilizers were applied at the rate of $\mathrm{N}_{100}+\mathrm{P}_{26}+\mathrm{K}_{40}+\mathrm{S}_{20}+\mathrm{B}_{1} \mathrm{~kg} / \mathrm{ha}$. Two - thirds of $\mathrm{N}$ and total amount of other fertilizers were applied at sowing and the remaining $\mathrm{N}$ was top dressed after first irrigation. Weeding was done at 25- 27 DAS by 2-4-D amine @ $1200 \mathrm{ml} / \mathrm{ha}$. At maturity, two samples of each plot in 2 $\mathrm{m}^{2}$ for zero till-drill, PTOS, farmer's practices, and $2 \mathrm{x} 1.1 \mathrm{~m}$ for bed planting on 27 March 2009 were harvested. After threshed and cleaned, grain yields were recorded at $12 \%$ moisture content. Data on other plant characteristics during harvesting from each of the experimental plot were recorded, such as spike, plant height, spike length, spikelets/spike, grains/spike, thousand grain wt (TGW), and grain yield were recorded. Data were subjected to analysis of variance to sort out significant difference among treatments. DMRT was used to compare treatment means. 


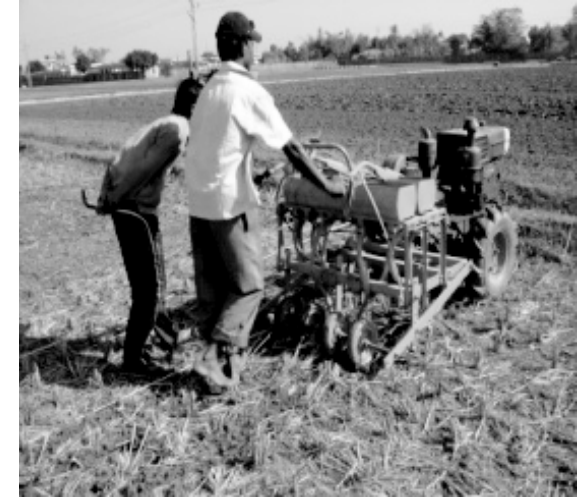

Fig. 1. Zerp till-drill

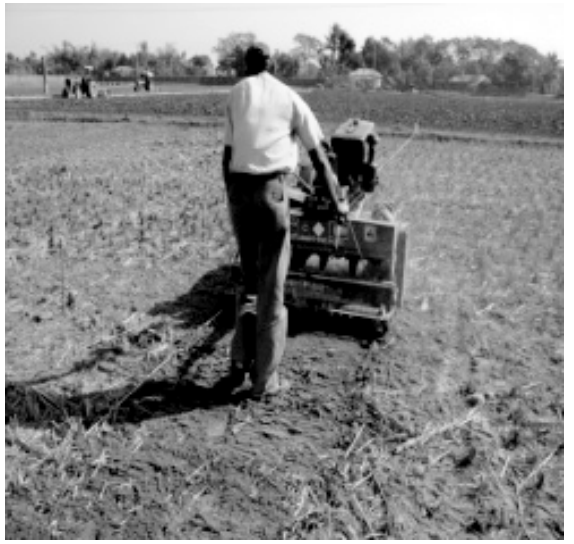

Fig. 3. PTOS

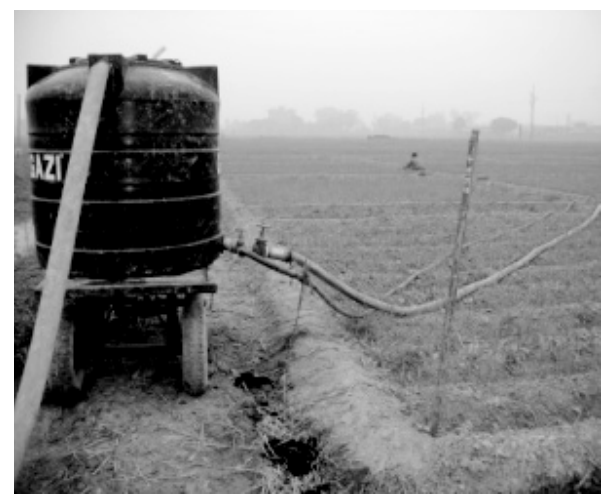

Irrigation water (IR) supply

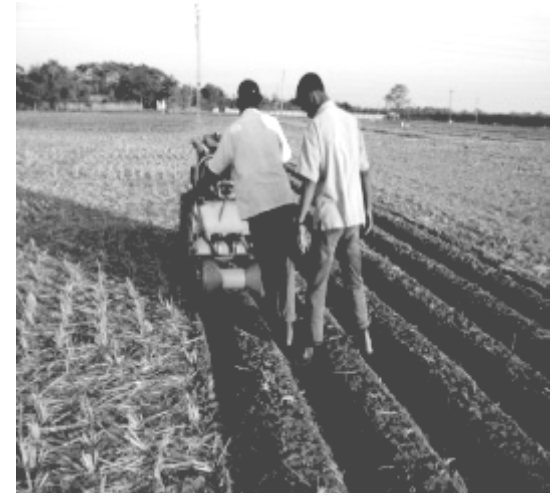

Fig. 2. Bed planting

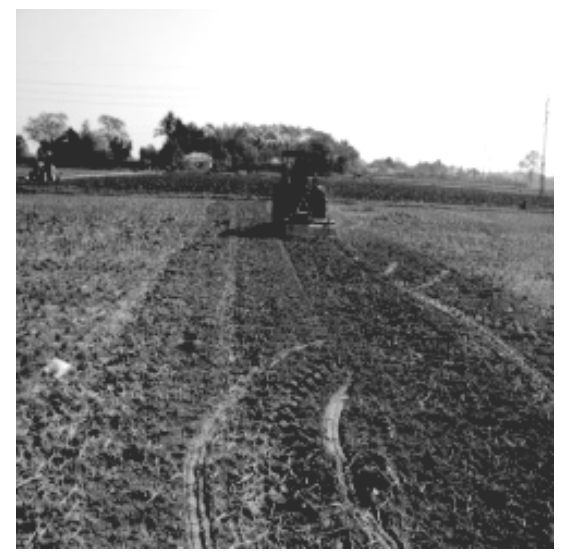

Fig. 4. Farmer's practice (FP)

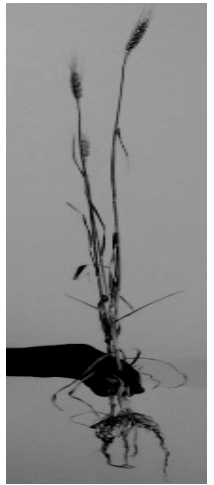

Without IR

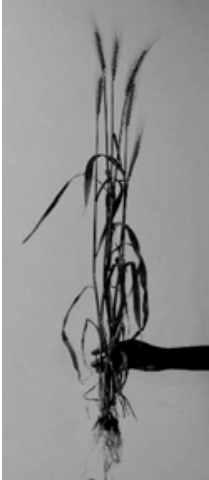

With IR 


\section{Results and Discussion}

Based on the analyses of weather data, the mean monthly minimum and maximum temperatures, relative humidity, total rainfall, sun-shine, and evaporation were shown in Fig. 5, respectively. It has been observed that temperatures were nearly optimum for wheat production. The sun-shine (hr) was not more. The rainfall was very low $(15.2 \mathrm{~mm})$ during wheat season. Pan evaporation was normal.
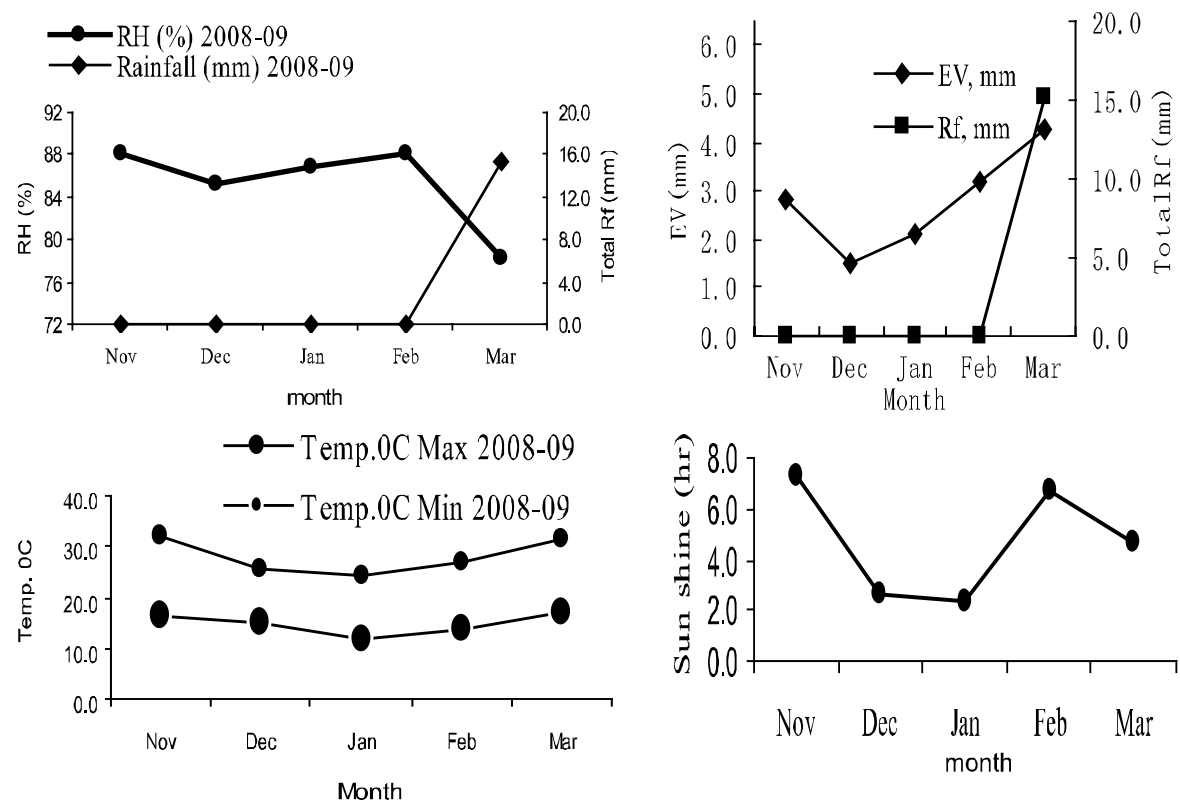

Fig. 5. Mean mothly weather data for the growing season of wheat, 2008-09

The average bulk density, field capacity and soil moisture during sowing were $1.57 \mathrm{~g} / \mathrm{cc}, 24 \%$, and $18 \%$, respectively. The soil type was sandy loam. According to the tillage methods, the sowing cost of wheat in zero tillage, PTOS and bed planting were 58, 56 and $47 \%$ less than that of farmer's practice (Table 1). Similar findings have been reported from the annual research report of Wheat Research Centre (WRC, 2009). The causes of variation of planting cost in different tillages were for different field capacities during operation. Besides this, less time and labour were required than farmer's practice. 
Table 1. Cost of sowing by different tillage methods for wheat.

\begin{tabular}{lc|c}
\hline \multicolumn{1}{c|}{ Tillage } & Cost of sowing (Tk./ha) & $\begin{array}{c}\text { Percent reduction } \\
\text { of sowing cost }\end{array}$ \\
\hline Farmer's practice ( 3 passes) & 4446 & - \\
Zero tillage ( 1 pass) & 1853 & 58 \\
Power tiller operated seeder ( 1 pass) & 1976 & 56 \\
Bed planting ( 1 pass) & 2347 & 47 \\
\hline
\end{tabular}

Seasonal water requirement was different in different tillage and irrigation options. About 10 percent seasonal water was less required in the tillage system of PTOS than that of farmer's practice under treatment, $\mathrm{I}_{4}$ (four irrigation) as shown in Table 2 due to conserving more soil moisture, uniformly mixing of soil particles with organic matter and broken capillary tube. Irrigation water was saved during irrigation due to quick advances of streams in untilled soil than tilled soil.

Table 2. Seasonal water use in conservation tillage under different irrigation levels.

\begin{tabular}{l|c|c|c|c}
\hline \multirow{2}{*}{ Irrigation no.(IR) } & \multicolumn{4}{|c}{ Seasonal water use, mm } \\
\cline { 2 - 5 } & \multicolumn{4}{|c}{ Tillage method } \\
\cline { 2 - 5 } & ZT & BP & PTOS & FP \\
\hline $\mathrm{I}_{0}$ & 74 & 75 & 73.9 & 74 \\
$\mathrm{I}_{1}$ & 109 & 119 & 104 & 107 \\
$\mathrm{I}_{2}$ & 159 & 172 & 147 & 147 \\
$\mathrm{I}_{3}$ & 192 & 202 & 190 & 193 \\
$\mathrm{I}_{4}$ & 200 & 231 & 195 & 215 \\
\hline
\end{tabular}

Table 3. The effect of different tillages on grain yield.

\begin{tabular}{lllll}
\hline \multicolumn{1}{c}{ Tillage method } & \multicolumn{1}{|c}{ Spikes $/ \mathrm{m}^{2}$} & \multicolumn{1}{c}{ G/Spike } & Grain yield $(\mathrm{kg} / \mathrm{ha})$ \\
\hline ZT & $310.5 \mathrm{a}$ & $39.4 \mathrm{~b}$ & $3315 \mathrm{~b}$ \\
BP & $295.9 \mathrm{~b}$ & $41.1 \mathrm{a}$ & $3393 \mathrm{~b}$ \\
PTOS & $\mathbf{3 1 8 . 8 a}$ & $\mathbf{3 9 . 9 a}$ & $\mathbf{3 5 8 9 a}$ \\
FP & $264.2 \mathrm{c}$ & $38.8 \mathrm{~b}$ & $3214 \mathrm{c}$ \\
\hline F-test & $*$ & $*$ & $* *$ \\
LSD & 12.35 & 1.4 & 46.86 \\
CV $(\%)$ & 7.47 & 5.11 & 3.83 \\
\hline
\end{tabular}


After data analysis for variance, there was no significant difference on the interaction effect of tillage and irrigation of grain yield. But, the effect of different tillage was found significantly differen for grain yield, spikes $/ \mathrm{m}^{2}$, and grains/spike (Table 3). The results indicated that more grain yield was observed in PTOS than that of farmer's practice due to uniform ploughing, seeding, leveling, proper seed placement, and good germination. Less grain yield was observed in farmer's practice due to less spikes $/ \mathrm{m}^{2}$ and grains/spike (Table 3) and improper placement of seed during sowing and also less seed germination. On average, 13, 6, and 7\% higher grain yields were found from PTOS, zero till-drill and bed planting, respectively, than that of farmer's practice.

Table 4. Percentage of grain yield (GY) increases in FP under different irrigations.

\begin{tabular}{|c|c|c|c|c|c|c|c|c|c|}
\hline \multirow[b]{3}{*}{$\begin{array}{l}\text { Irrigation } \\
\text { treatments }\end{array}$} & \multicolumn{8}{|c|}{ Grain yield (GY), kg/ha } & \multirow{3}{*}{$\begin{array}{c}\text { Average } \\
\% \text { of } \\
\text { grain } \\
\text { yield }\end{array}$} \\
\hline & \multicolumn{2}{|r|}{ ZT } & \multicolumn{2}{|r|}{ BP } & \multicolumn{2}{|c|}{ PTOS } & \multicolumn{2}{|r|}{ FP } & \\
\hline & GY & $\begin{array}{l}\% \text { of GY } \\
\text { increases }\end{array}$ & GY & $\begin{array}{l}\% \text { of GY } \\
\text { increases }\end{array}$ & GY & $\begin{array}{l}\% \text { of GY } \\
\text { increases }\end{array}$ & GY & $\begin{array}{l}\% \text { of GY } \\
\text { increases }\end{array}$ & \\
\hline $\mathrm{I}_{0}$ & 2472 & - & 2351 & - & 2680 & - & 2401 & - & - \\
\hline $\mathrm{I}_{1}$ & 3150 & 27 & 3294 & 40 & 3539 & 32 & 3202 & 32 & 33 \\
\hline $\mathrm{I}_{2}$ & 3431 & 39 & 3611 & 54 & 3783 & 41 & 3377 & 39 & 43 \\
\hline $\mathrm{I}_{3}$ & 3736 & 51 & 3769 & 60 & 3991 & 49 & 3530 & 45 & 52 \\
\hline $\mathrm{I}_{4}$ & 3784 & 53 & 3748 & 59 & 3953 & 48 & 3560 & 46 & 51 \\
\hline
\end{tabular}

Table 5. The effect of irrigation level on grain yield.

\begin{tabular}{l|l|l|l|l|l|l}
\hline \multicolumn{1}{c|}{ IR } & Spikes $/ \mathrm{m}^{2}$ & Spikelets $/ \mathrm{m}^{2}$ & Grains/spike & $\begin{array}{c}\text { TGW } \\
(\mathrm{g})\end{array}$ & $\begin{array}{c}\text { Grain yield } \\
(\mathrm{kg} / \mathrm{ha})\end{array}$ & $\begin{array}{c}\text { WUE } \\
\left(\mathrm{kg} / \mathrm{m}^{3}\right)\end{array}$ \\
\hline $\mathrm{I}_{0}$ & $265.7 \mathrm{~d}$ & $15.6 \mathrm{c}$ & $36.7 \mathrm{~d}$ & $55.2 \mathrm{~b}$ & $2476 \mathrm{~d}$ & $3.3 \mathrm{a}$ \\
$\mathrm{I}_{1}$ & $291 \mathrm{c}$ & $16.7 \mathrm{~b}$ & $37.5 \mathrm{c}$ & $56.2 \mathrm{~b}$ & $3296 \mathrm{c}$ & $3 \mathrm{~b}$ \\
$\mathrm{I}_{2}$ & $303.2 \mathrm{bc}$ & $17.7 \mathrm{a}$ & $41.8 \mathrm{a}$ & $57.8 \mathrm{a}$ & $3550 \mathrm{~b}$ & $2.3 \mathrm{c}$ \\
$\mathrm{I}_{3}$ & $\mathbf{3 0 8 . 2 a b}$ & $\mathbf{1 7 . 7 a}$ & $\mathbf{4 1 . 8 a}$ & $\mathbf{5 8 . 8 a}$ & $\mathbf{3 7 5 6 a}$ & $1.95 \mathrm{~d}$ \\
$\mathrm{I}_{4}$ & $318.7 \mathrm{a}$ & $17.3 \mathrm{a}$ & $41 \mathrm{~b}$ & $58.2 \mathrm{a}$ & $3762 \mathrm{a}$ & $1.8 \mathrm{~d}$ \\
\hline F-test & $*$ & $*$ & $* *$ & $*$ & $* *$ & $* *$ \\
CV (\%) & 7.47 & 2.56 & 5.11 & 1.32 & 3.83 & 5.92 \\
LSD & 14.65 & 0.53 & 0.67 & 1.11 & 122.2 & 0.059 \\
\hline
\end{tabular}

The effect of irrigation level was found highly significant on grain yield and the other yield contributing characters (Table 5). It was observed that grain yield in different tillage operations were increased with increased number of irrigation levels. Maximum grain yield was obtained from $\mathrm{I}_{3}$ level (Three number of irrigations). There was no significant difference on maximum grain yield at $\mathrm{I}_{3}$ and 
$\mathrm{I}_{4}$ level of irrigation. On average, $33,43,52$, and $51 \%$ yields were increased than that of farmer's practice under $\mathrm{I}_{1}, \mathrm{I}_{2}, \mathrm{I}_{3}$, and $\mathrm{I}_{4}$ irrigation levels, respectively (Table 4). These results indicated that wheat was quite responsive to increase yield in optimal or near optimal irrigation. Water use efficiency (WUE) was found significant (Table 5). The results indicated that water use efficiency was found to differ, increase due to less seasonal water use and decrease with increased irrigation. The figures (* and $* *$ ) within the column indicate $5 \%$ and $1 \%$ level of significance.

\section{Conclusions}

From one year study, the experiment supports the following conclusions:

(i) The sowing cost of wheat could be reduced up to 47,56 , and $58 \%$ by bed planting, PTOS, and zero tillage than conventional practice, respectively.

(ii) There was no significant difference within the interaction effect of tillage methods and irrigations. About 10 percent seasonal water use was less in PTOS than farmers' practice under four irrigations.

(iii) The grain yield in that situation was higher from PTOS, bed planting and zero tillage than farmer's practice. On average, 13, 6, and 7\% grain yields were found higher from PTOS, zero tillage and bed planting than farmer's practice, respectively.

(iv) The effect of irrigation level was found highly significant. Average $33,43,52$, and $51 \%$ yields were increased under $\mathrm{I}_{1}, \mathrm{I}_{2}, \mathrm{I}_{3}$, and $\mathrm{I}_{4}$ irrigation levels, respectively.

(v) Optimum water use of zero till-drill, bed planting, PTOS, and farmer's practice were 192, 202, 190, and $193 \mathrm{~mm}$, respectively, under $\mathrm{I}_{3}$ irrigation level.

\section{Acknowledgements}

The authors wish to express their deep sense of gratitude and acknowledge Wheat Research Centre under Bangladesh Agricultural Research Institute (BARI), Department of Farm Power and Machinery, and Irrigation and Water Management for the arrangement of research facilities. The author is grateful to Director General of BARI for providing fund for the research. The authors also acknowledge their heartfelt gratitude to CIMMYT Bangladesh for providing partial research facilities in WRC of BARI, Nashipur, Dinajpur, Bangladesh. The authors acknowledge the contribution of scientists of WRC and scientists of Irrigation and Water Management Division, BARI for suggestions. The authors also acknowledge the contribution of Dr. K. D. Sayre, Agronomist, CIMMYT, Mexico for providing technical help for the research work. The authors express 
their thanks to Dr. A. Z. Sarker, SSO, Agronomy Division, DR. P. K. Malaker, PSO, WRC, BARI and A. F. M. Tariqul Islam, SO, ASICT section, BARI for preparing and analyzing the data. The authors acknowledge with great respect Dr. P. K. Sarkar, PSO, Irrigation and Water Management Division, BARI for preparing the report properly and correctly. The author would like to thank engineering workshops, office, and field staff of WRC for successful completion of the research work. Finally, the principal authors would like to express their sincere appreciation and gratitude to his wife and twin sons for their sacrifice, cooperation and encouragement during the research works.

\section{References}

Abdelhadi, A. W., M. A. Bashir, S. E. A. El Awad, Takeshi Hata. 2006. Evaluation of Wheat Bed Planting Method in Irrigated Vertisols of Sudan. Agricultural Mechanization of Asia, Africa \& Latin America, Vol. 37. No. 3

Ali, Nawab. 2009. Resource Saving Equipment for Conservation Agriculture Leading to Higher Productivity and Profitability. $4^{\text {th }}$ World Congress on Conservation Agriculture, 4-7, New Delhi, India. P. 192.

Aslam, M., A. Majid, N.I. Hashmi and P.R. Hobbs. 1993. Improving wheat yield in the rice-wheat cropping method of the Punjab through zero-tillage. Pakistan J. Ag. Res. 14: 8-11.

Bodruzzaman, M., M. H. H. Khan, M.A. Shaheed and A. S. M. G. Amin. 2003. Response of Wheat to Different Rates of Phosphorus and Potassium Application. Bangladesh Journal of Agricultural Research, Volume 28, Number 4, December.

BBS. 2004. Statistical Year Book of Bangladesh. Bangladesh Bureau of Statistics, Dhaka, Bangladesh

De Datta, S. K. 1981. Principles and Practices of Rice Production, Jhon, Wily \& Sons)

http://www.fao.org/ag/ca/1a-html. FAO web site: The role of conservation agriculture in sustainable agriculture.). accessed on November 2008.

ISTRo-INFO EXTRA, 1999. Webpageat: http://www.Soils.wisc.edu/stro. Vol. 4,

Justice, S., E. M. Haque, C. A. Meisner, I. Hossain, Ganesh Sah, J. Tripathi, M. H. Rashid, M. R. Amin. 2004. Giving South Asia Farmers Choice: A single drill for Reduced and Strip Till Crops for 2-wheel tractors, Proc. Int. Conf. Beijing Sponsored by CIGR, CSAM and CASE Beijing, China11-14 October.

Khair, A. 1995. Water application methods for diversified crops. Crop Diversification; Findings from a field Research Programme, P43. The University Press Ltd.

Michael, A. M. 1996. Irrigation Theory and Practice. Vikas Publishing House PVT. LTD, New Delhi, P. 512.

Sarker, R. I.,1987. Effect of Tillage on Water Use. Bangladesh Journal of Agricultural Engineering Vol. 1, No. 1.

Sattar, M. A. 2004. Irrigation Principles and Practices: A Review. p. 61

WRC. 2008. Annual Research Report. Wheat Research Centre, BARI, Nashipur, Dinajpur.

WRC. 2008-09. Annual Research Report. Agricultural Engineering Division, Wheat Research Centre (WRC), Dinajpur. Paper Presented in the Internal Research Review Workshop of WRC held in BARI, Gazipur, p. 8 